\title{
1. Introduction: Asia-Pacific resource politics between boom and crisis
}

For the first time since the energy crises of the 1970s, resource security has re-emerged on the international agenda. Rising international prices, surging demand from developing countries and concerns about scarcity have seen resources become a major policy concern during the 2000s. In the Asia-Pacific, these issues have become particularly salient. For resource-rich countries such as Australia, Russia and Indonesia, the recent 'global resource boom' has offered significant opportunities. Rising prices have provided governments new sources of revenue, enabled resource-led development strategies and, in some cases, seen resource wealth leveraged for diplomatic influence. But for the region's resource-poor consumers Japan, China and Korea - the boom has instead manifested as a 'resource crisis'. These governments have struggled with soaring import bills, threats to the economic security of industry and households, and the challenge of managing relationships with 'problematic' resource suppliers. Deep patterns of interdependence in the region - with trade and investment ties connecting resource-rich producers on the Pacific Rim to resource-poor consumers in East Asia - mean that policymakers understand resource security as an international issue.

International resource politics in the Asia-Pacific has become highly charged. Despite high levels of regional interdependence, the last decade has seen the outbreak of several inter-governmental disputes over which parties will gain access to resources, from whom and on whose terms. Consumer governments in Northeast Asia have become locked in a 'race for resources', competitively deploying financial and diplomatic capital to gain privileged access to foreign mineral and energy supplies. Producer governments have exploited the boom to demand payoffs from customers and multinational resource firms through nationalistic policy regimes which restrict international trade and investment. Some governments - particularly China and Russia - have used resources as a diplomatic weapon, threatening to withhold supply to extract concessions and side-payments from partners. Energy security concerns have exacerbated territorial disputes in the East and South China Seas, where competing ownership claims over subsea hydrocarbons have driven aggressive 
behaviour by regional governments. Resources have also become a factor for great power rivalry in the Asia-Pacific, with many recent diplomatic clashes between Japan, China and the United States originating in contests over how resource interdependence should be governed. Some analysts have gone as far to suggest that resource competition will stoke inter-state conflict - and potentially war - in the Asia-Pacific in years to come.

This book examines international resource politics in the Asia-Pacific during the recent global boom to explain the causes and consequences of these emerging conflicts. Conceptually, it moves beyond existing International Relations (IR) scholarship, which tends to view international resource politics as a primarily inter-state game played over ownership, control and access (Stoddard 2013). This IR literature is characterised by a debate between a realist-inspired geopolitical approach that views resource relationships as a conflictual zero-sum game; and a liberal-influenced global governance approach which emphasises cooperative dynamics and interdependence (Dannreuther 2013; Dent 2013). However, these approaches face explanatory difficulties. By adopting a solely international-systemic perspective, they neglect other sites of resource politics - particularly at the domestic level - that influence inter-state resource relationships. They also fail to examine why governments consider natural resources to be a securitised policy domain. While many have critiqued these limitations, scholars are yet to develop alternate approaches which theorise the drivers of international resource politics beyond the systemic level.

This book is an intervention into the IR literature on international resource politics. To address these explanatory deficiencies, it develops a political-economy-based theorisation of inter-governmental resource relationships. Its conceptual approach views natural resources not simply as an 'asset' or 'liability' for a state's foreign policy agenda, but as an issue area subject to the process of securitisation. Its point of departure is to interrogate the conditions under which resource interdependence becomes securitised - the political process whereby governments frame resources as an existential threat to state interests. Securitisation is a contingent process which results from economic and political dynamics occurring at both the domestic and international levels. Securitisation has significant implications for inter-state resource politics. It encourages governments to take a nationalistic approach to resource issues, undermines schemes for cooperative institution building, and produces an environment where resource interdependence is viewed as a rivalrous zero-sum game. When securitising pressures are high, these dynamics precipitate inter-state conflict over how the benefits of interdependence are shared. To explain international resource politics, scholars must go beyond the systemic level and look to the political economy drivers behind the securitisation of resource policy. 
The book develops and substantiates this theoretical argument through a detailed study of the Asia-Pacific region. The Asia-Pacific is selected for analysis as it is perhaps the most important site of resource politics in the contemporary world. The region is home to both some of the world's most resource-hungry economies (such as China, Japan and the United States), as well as some of the most resource-rich states (Australia, Russia, Indonesia and Brazil). The book explores the drivers of international resource politics in the Asia-Pacific in two ways. First, it uses a comparative method to examine resource policymaking in producer states, consumer states and regional organisations. It traces how distributional contests over rents have seen governments securitise resource issues which led to the adoption of economic nationalist policy approaches. Next, the book adopts a case-study method to investigate three important resource conflicts in the region: the Northeast Asian scramble for oil and gas, Australia-China disputes over iron ore, and diplomatic wrangling amongst China, Japan and the United States over rare earth minerals. These case studies demonstrate how increasing securitisation has seen inter-state resource relationships become conflictual in recent years, which has, in turn, contributed to broader political tensions amongst Asia-Pacific governments.

\section{RESOURCE INSECURITY AND INTERNATIONAL POLITICS IN THE ASIA-PACIFIC}

The rising significance of natural resources in international politics is largely due to the 'global resources boom' from 2004 to 2013. Driven by industrialisation and urbanisation in the developing world, demand for minerals and energy has grown strongly. In the decade to 2012, global consumption of oil increased by 12 percent, natural gas by 28 percent, coal by 44 percent, and steel by 58 percent. ${ }^{1}$ Much of this demand has been associated with China's shift towards a 'heavy' stage of industrialisation, based on rapid growth in the construction, machinery and automotive sectors (Jiang and Lin 2012). But China is not the sole driver. A wide range of industrialising economies in the developing world, including India, Indonesia, Nigeria, Russia, Brazil, Mexico, Turkey and Vietnam, have also made a major contribution to the resource consumption boom of the 2000s (Lee et al. 2012). Indeed, non-OECD countries accounted for all of the 25 percent growth in global primary energy consumption which occurred during the last decade. ${ }^{2}$

Unfortunately, the workings of international resource markets mean global supply failed to keep pace with developing-world demand. The long 
Figure 1.1 International resource price indices during the global boom, 2000-14

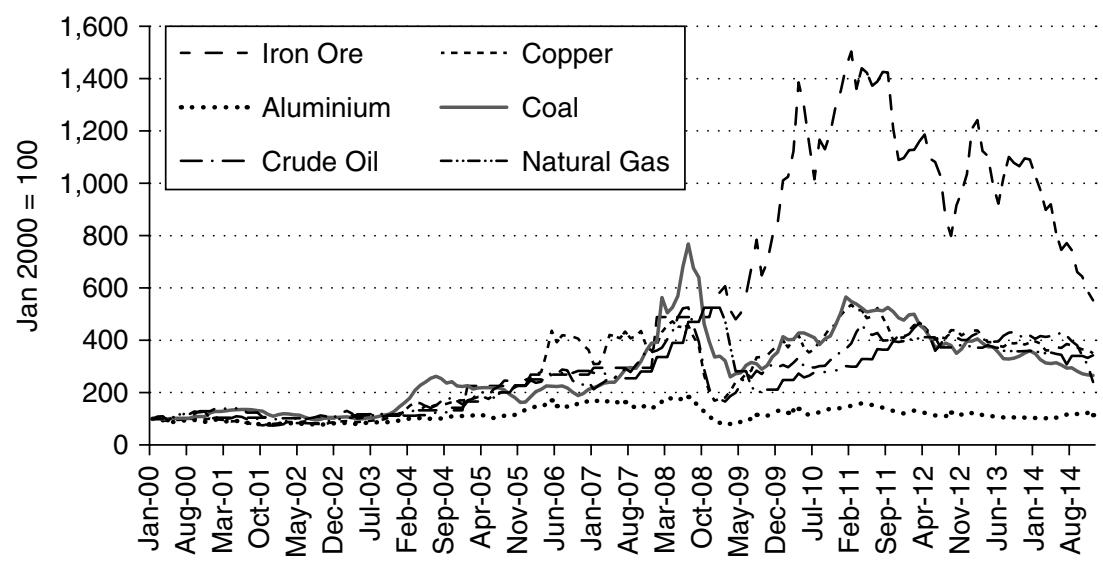

Source: Author's calculations, from (IMF 2015).

lead-times facing mining and energy investments - often of five to ten years - create lags between demand, investment and new supply. For some hydrocarbons, diminishing conventional reserves have also posed technical challenges associated with exploiting new non-conventional sources, such as shale oil, biofuels and ultra-deepwater basins (Bentley 2002). These factors saw world resource markets begin a period of unprecedentedly rapid growth in 2004. By the peak of the cycle, most minerals and energy prices had increased between four- and six-fold, while iron ore at one point traded at fifteen times its pre-boom levels (see Figure 1.1). Cross-border investment in resource industries also surged, as multinational resource firms expanded production to capitalise on record-level prices (Figure 1.2). Economists have labelled the boom of 2004-13 a 'commodities supercycle', during which resource markets became detached from cycles in the broader global economy (McKinsey Global Institute 2013). Demand growth proved so robust that even the global financial crisis of 2008-09 caused little more than a dip in an otherwise secular and decade-long trend of rising prices.

In Asia, the principal consequence of the boom has been a marked deterioration in resource security: the availability of appropriate natural resources at affordable prices. In part this is because Asia is comparatively resource-poor. Japan, Korea and most Southeast Asian countries have very few mineral and energy reserves, and the few resource-rich economies in the region (China, India and Indonesia) possess some resource 
Figure 1.2 Cross-border mining and energy investment, 1990-2013

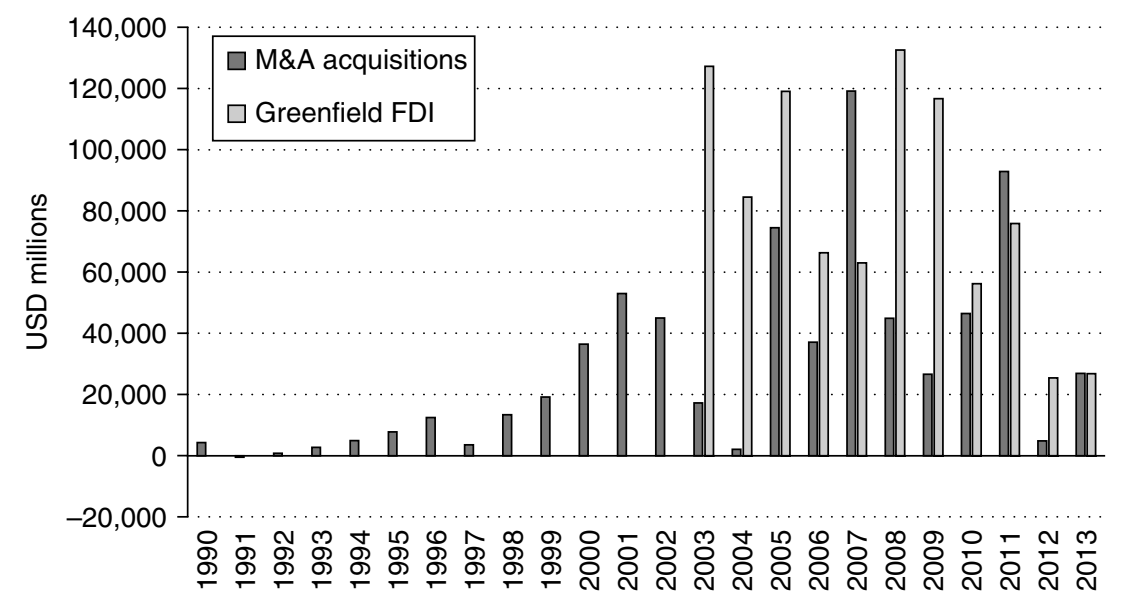

Note: Greenfield FDI data only available from 2003.

Source: (UNCTAD various years).

commodities but not others. Yet Asia is also one of the most resourcehungry regions in the world. The advanced economies of Northeast Asia have very high levels of energy consumption, while Southeast Asia is home to rapidly industrialising and urbanising countries whose demand for resources is soaring. Compounding matters, rural and urban poverty in developing Asia also contributes to the problem of energy poverty facing marginalised social groups (Sovacool 2012). As will be discussed in Chapter 3, the paucity of local reserves has forced Asia to import massive volumes of mineral and energy: some $\$ 1.4$ trillion by the ASEAN $+3^{3}$ in 2013, equivalent to 31 percent of their merchandise imports. This places Asian economies squarely on the wrong side of the global boom, facing rapidly escalating resource costs while obtaining few of the benefits accruing to resource producers. Many governments - including Japan, China and Korea - have responded to this threat by adopting formal energy or resource security strategies.

Nonetheless, Asian resource consumers are fortunately positioned in terms of geography, as the broader Asia-Pacific region is home to a range of resource-rich economies. On the Pacific Rim, Australia, Russia, Brazil and the United States are all major mineral and energy exporters. Within Southeast Asia, Indonesia, Malaysia and Myanmar each possess sizeable reserves of oil and gas. The resource boom has provided a fillip to these economies, particularly through rising export revenues and inflows of 
foreign investment. Importantly, economic complementarity between the region's producer and consumer economies has produced deep patterns of resource interdependence. In terms of trade, there is a vigorous seaborne trade in resources from exporting countries on the Pacific Rim to consumption centres in Asia. Flowing in the opposite direction, foreign investment from Northeast Asian industrial conglomerates helps to finance mining and energy projects across the Pacific region. These trade and investment ties are mutually beneficial for all - providing producers with export opportunities, while helping to address the resource insecurity of consumers. As a result, regional resource interdependence in the AsiaPacific is very deep. In 2014, 48 percent of the minerals and energy trade of the member economies of Asia Pacific Economic Cooperation (APEC) was conducted with other members of the regional grouping. 4

Resource interdependence might ostensibly be expected to function as a source of international cooperation in the region. As liberal-influenced IR analyses have argued, interdependence between consumer and producer economies creates incentives for governments to cooperate to achieve shared resource security goals (Dubash and Florini 2011; Goldthau and Witte 2009). However, the recent experience of Asia-Pacific resource politics fails to conform to this optimistic expectation. Governments often have competing interests from resource interdependence: with producers favouring buoyant markets and high prices, while consumers prefer stable, low prices. The strategic importance of natural resources - for both the economic and military security of governments - has also led many governments to consider resource interdependence a securitised issue. These tensions can potentially become the basis for inter-state resource conflicts distributional conflicts over which parties get access to minerals and energy, from whom, on whose terms and at what price. Such conflicts have become commonplace in the Asia-Pacific during the recent global boom.

Some of these conflicts have pitted consumer states against each other in a race to secure access to foreign resources. Suffering the economic effects of high prices, and fearful that imports may be interrupted for political reasons, the Japanese, Korean and Chinese governments have each launched competitive resource security strategies. These have used financial and diplomatic tools to carve out nationally controlled supply networks, designed to give their economies access to resources on better terms than their peers (Herberg 2010; Jain 2014). Others have taken the form of producer-consumer conflicts, as resource-rich governments have exploited the boom to enact nationalistic resource policies. Countries as diverse as China, Indonesia, Kazakhstan and Russia have been dragged into disputes with customers over the terms on which access to local resource markets would be granted (Domjan and Stone 2010; Hughes 
2011; Wilson 2015a). Sovereignty over resource endowments is also implicated in several multilateral security tensions in the region, particularly maritime territorial disputes presently intensifying in the East and South China Seas (Emmers 2013). Many analysts have claimed that these interstate resource disputes are threatening to destabilise already tense relations between the major powers in the region (Herberg 2010; Leverett 2009; Phillips 2013).

These emerging patterns of conflict require explanation. Resource security is an increasing policy challenge, and regional interdependence potentially offers benefits for all parties. Why, then, has resource politics in the Asia-Pacific been predominantly characterised by internecine intergovernmental conflict? Addressing this puzzle requires scholars to theorise the role of natural resources in international politics. How do governments approach resource interdependence as a policy issue? What are the principal political and economic factors - be they at the domestic, regional or global levels - influencing their resource policy strategies? And how do these national resource strategies condition patterns of conflict and cooperation in inter-governmental resource relationships?

\section{INTERNATIONAL RELATIONS APPROACHES TO RESOURCE POLITICS}

Political scientists are paying significant attention to questions regarding natural resources and international politics. While resources had been a dominant theme in international relations following the energy crises of the 1970s, their importance waned as energy issues fell from the international agenda during the 1990s (Hancock and Vivoda 2014). However, recent years have seen the emergence of a new scholarly literature on international resource politics, dedicated to understanding emerging trends during the global boom of the 2000s. Most contributions come from the IR literature and deploy a systemic perspective to frame resource politics primarily as a foreign policy issue. Two accounts dominate this literature: a geopolitical approach that views resources as a site of zero-sum competition between governments; and a global governance approach that emphasises the positive-sum and cooperative character of resource interdependence (Dannreuther 2013). However, the explanatory power of both approaches is limited by their emphasis on systemic factors at the expense of other dimensions of resource politics.

A geopolitical approach, which is broadly (though often implicitly) associated with the realist IR paradigm, claims that conflict tendencies are inherent to resource interdependence. Adopting an 'access-based' view of 
resource security, it emphasises that minerals and energy are scarce and unevenly distributed amongst states, yet are also essential for economic and military security (Haglund 1986). The risk that supplies may be interrupted therefore means resources are a 'securitised' policy domain, which takes the form of zero-sum competition for access to limited supplies (Jain 2014; Klare 2012). While this means international resource conflicts are a natural (and somewhat unavoidable) phenomenon, their frequency and intensity are causally connected to levels of geopolitical stability. Some attribute blame to changing security alignments, identifying declining US hegemony (Wesley 2007) and emerging patterns of great power rivalry (Phillips 2013) as producing a context favouring resource conflicts. Others draw attention to territorial disputes in the region - particularly in the oil and gas rich South China Sea - as contributing to inter-governmental resource rivalry (Buszynski 2012; Thomson 2006). Others point towards the aggressive behaviour of certain states, particularly China and Russia, as a driver of emerging conflicts (Baev 2015; Economy and Levi 2014). Whatever the proximate cause, the geopolitical approach views resources as a domain of zero-sum competition due to their inherently securitised nature.

In contrast, a global governance approach draws on ideas from liberal IR theory to emphasise cooperative dynamics. It starts with the claim that resource security is inherently an issue of interdependence - no state possesses all the diverse range of minerals and energy it requires, and therefore all are obliged to rely on others for supply through international markets (Sovacool 2011a; Verrastro and Ladislaw 2007). Instead adopting what Chester (2010) labels a market-based conception of resource security, it contends that interdependence will lead to cooperative inter-state relations through one of two mechanisms. First, open, competitive and flexible international markets are argued to serve the economic interests of both producers and consumers. International markets thus function as a 'global public good' which improves the resource security of all economies (Dubash and Florini 2011; Harris and Naughton 2007). Second, the potential for market failures means there is a strong incentive for governments to take collective action to support and augment these markets. This is evident through a range of inter-governmental institutions which act to disseminate information, coordinate national policies and allow negotiation over how the costs and benefits of interdependence are shared (Goldthau 2011; van de Graaf 2013). Taken together, Goldthau and Witte (2009) argue that the presence of international markets and institutions functions as 'rules of the game' for resources, ameliorating conflict and encouraging positive-sum cooperation.

However, an explanatory difficulty facing both IR approaches is their 
conception of international resource politics as a primarily inter-state game. Whether viewed as zero-sum and conflictual, or positive-sum and cooperative, both approaches privilege the systemic level of analysis. Resource security is viewed as a foreign policy problem, and state behaviour is explained solely through inference to international dynamics. No attempt is made to explore the influence of other sites of resource politics, particularly those at the domestic level, on state policy strategies. Significantly, neither provides an adequate account of why - or indeed, whether - governments consider resources a securitised policy domain. This privileging of systemic factors means existing IR approaches fail to 'open the black box' of the state or to examine how domestic politics combines with international strategic considerations in shaping how governments understand resources as a security issue. For these reasons, many scholars have criticised the dominance of these IR approaches and called for a re-theorising of international resource politics that moves beyond the systemic to explore political economy dynamics at multiple levels (Keating et al. 2012; Hughes and Lipscy 2013; Dannreuther and Ostrowski 2013; Stoddard 2013).

\section{SECURITISATION AS THE DRIVER OF INTERNATIONAL RESOURCE POLITICS}

This book develops a political-economy-based approach to international resource politics which places securitisation at the centre of analysis. Its point of departure is the observation that governments frequently securitise resource policy: a process where an issue is framed as an existential threat to political order, which legitimises the deployment of 'extraordinary' responses to the securitised threat (Buzan, Wæver and de Wilde 1998). Securitisation is a subjective and contingent process which occurs when powerful actors consider an issue a threat to some set of interests and discursively frame it in these terms (Williams 2003). Once an issue is discursively framed as a security threat by a government (or group of governments), it becomes considered special and in need of state intervention to address (Roe 2012). In the domain of economic policy, securitised issues become a 'quasi-reserved domain', in which economic logics are subsumed by national security concerns (Higgott 2004). In this way, securitisation is the variable that structures the way governments approach resource interdependence, by influencing their perceptions of how resources influence state interests and the policy decisions they make.

Due to their systemic mode of theorising, existing IR approaches inadequately conceptualise securitisation. The geopolitical approach assumes 
securitisation due to the existential importance of resources for economies and militaries; while the global governance approach assumes away securitisation through a functionalist account of the benefits of markets and institutional cooperation. This book instead seeks to explain resource securitisation by drawing upon the scholarly literature on the political economy of natural resources. This literature unpacks the securitisation process by looking to political dynamics - at both the domestic and international levels - which shape state preferences over resource policy. While this political economy literature offers considerable insights into the securitisation process, its findings are rarely drawn together, nor explicitly connected to IR debates over resource interdependence. By consolidating insights from this political economy literature, this book develops a three-stage theoretical model to explain how securitisation drives patterns of international resource conflict and cooperation.

First, it argues that governments securitise resources due to their role in many security domains. In many countries, resources are considered an important economic security concern. In consuming economies, this is often associated with the protection of privileged economic interest groups (including industrial firms and those connected to political elites) (Victor 2009). In producing countries, it concerns how resource revenues are used by the state for economic and developmental purposes and thus are distributed amongst competing societal claimants (Nem Singh 2012). Resources also cut to issues of regime security, where ruling elites use resource wealth for political legitimation. This is especially true of so-called rentier states, whose political institutions are built around the capture and distribution of resource rents by state agencies (Luciani 1990). Both authoritarian and democratic rentier states depend on resource rents to secure regime legitimacy (Dunning 2008; Morrison 2009). Resources may also be included in broader concerns regarding geopolitical security. As important but globally scarce assets, resource endowments are a tool which governments can exploit to advance foreign policy goals. This is especially pronounced for governments with uncertain geopolitical positions, which often turn to 'resource statecraft' as a source of international influence (O'Sullivan 2013; Stulberg 2007). The perception that developments in the resource sphere may existentially threaten economic, regime and/or geopolitical interests leads governments to securitise resource policy.

Second, securitisation leads governments to adopt economic nationalist resource policy regimes. Rather than leaving resource exploitation to market forces and the decisions of private firms, governments intervene in these sectors to control these existentially important sectors. In producing states, this often takes the form of so-called resource nationalist policies, such as state ownership, industrial policy interventions, trade and 
investment controls, and special fiscal regimes (Mares 2010; Vivoda 2009). These policies are used to capture resource rents for the state, which can then politically manage their use to protect certain security interests. In consuming countries, economic nationalism manifests instead as 'resource mercantilism', a security strategy based on foreign investment by stateowned firms and resource diplomacy with key supplier governments (Herberg 2010; Leverett 2009). These financially and diplomatically costly strategies are designed to lessen reliance on international markets, enabling state agencies to socialise and manage the risks of resource insecurity. These inter-related forms of economic nationalism mean most governments favour state- rather than market-based resource policy regimes, resulting in comparatively high levels of state control of international markets.

Third, securitisation and economic nationalism within states play a decisive role in shaping patterns of resource politics between them. They influence how states perceive interdependence, by encouraging individualistic, competitive and go-it-alone responses to resource insecurity. They raise the perceived sovereignty costs of formal and rules-based intergovernmental cooperation, resulting in a bias towards 'soft law' schemes designed to preserve national policy autonomy. They politicise and distort the operation of international markets, which lowers states' confidence that markets will function as a cooperative public good. Together, these effects create an environment prone to conflict. Governments fail to develop effective cooperative institutions, become wary about reliance on international markets and ultimately view resource interdependence as a rivalrous zerosum game. The result is the outbreak of inter-state resource conflicts, as governments clash over how the benefits (and costs) of interdependence are distributed.

These considerations allow for the construction of a theoretical model which identifies securitisation as the driver of international resource politics. Securitisation is conceptualised not as a constant feature, but a variable process. It is contingent on both economic dynamics (namely, cycles in world resource markets) as well as political factors specific to certain important states (such as resource dependency, rentier institutions and complicating geopolitical relationships). When these securitising pressures are high, governments respond with economic nationalist policies. These encourage rivalrous behaviour and create an environment prone to inter-state conflict. Conversely, when securitising tendencies are low, governments are less likely to adopt these nationalistic policies. This instead enables forms of cooperative behaviour, by augmenting markets and enabling cooperation for shared energy goals. Securitisation is therefore the variable which determines which behavioural logic is dominant. High 
securitisation creates conflictual, geopolitical-type behaviour, while low securitisation enables a cooperative, global governance logic instead.

This political economy approach offers several explanatory advantages over prevailing theories of international resource politics. Perhaps most importantly, it addresses the systemic bias of IR accounts by considering both the domestic and international determinants of state behaviour. Domestic and international political imperatives are not hermetically separated, and governments consider both when deciding upon resource policy strategies. It also explicitly problematises the factors behind the securitisation of resources. By looking to their role in economic, regime and geopolitical security, it explains securitisation as a process contingent on certain economic dynamics and political processes occurring within states. Moreover, this political-economy approach helps move beyond the reductive 'conflict-or-cooperation' debate that presently characterises the IR literature. Rather than framing resource interdependence as an inherently conflictual or cooperative international game, it argues that both dynamics are concurrently at play, with the balance determined by economic processes in resource industries and the politics that accompany them.

\section{THE ASIA-PACIFIC AS THE EPICENTRE OF CONTEMPORARY RESOURCE POLITICS}

The book develops this argument through a detailed analysis of international resource politics in the Asia-Pacific during the recent global boom. The Asia-Pacific region is defined as the economies of East Asia (as encapsulated by the ASEAN+3 group) plus their principal minerals and energy suppliers. Two groups of suppliers are included: those in Eurasia engaged in overland resource trade with East Asia (Russia and Kazakhstan) and those engaged in seaborne trade across the Pacific (including Australia, Brazil, Chile, Indonesia, the Gulf States and the United States). A regional, rather than global, focus is adopted due to the regionalised nature of world resource markets. Due to the high transport costs and infrastructural considerations facing bulk commodities, most international minerals and energy trade is segmented into regional markets. ${ }^{5}$ As these markets are differentiated by their membership, industry structures, governance institutions and economic dynamics, patterns of international resource politics vary on a regional basis.

The Asia-Pacific is selected as the region for analysis for several reasons. In economic terms, Asia is central to recent dynamics in global resource markets. The region is home to both the industrialised states of Japan and Korea, as well as the industrialising and urbanising economies of 
Southeast Asia and China, where consumption is rapidly rising. Indeed, Asian industrialisation is the primary cause of the global resource boom. The total primary energy consumption of the ASEAN+3 group grew by 68 percent in the decade to 2012, and accounted for two-thirds of the increase in global energy consumption during this period. ${ }^{6}$ Resources have also been a major driver behind economic integration in the region. This process was first led by Japanese trade and investment ties with Pacific Rim suppliers established from the 1960s, and was more recently augmented by China's 'Going Out' resource investment programs of the 2000s (Wilson 2013; Zhao 2012). The Asia-Pacific is the most important regional site for international resource politics today.

Minerals and energy issues also loom large in the international politics of the Asia-Pacific. Resources are of major policy significance to governments in the region: whether due to resource insecurity facing consumers such as China, Korea and Japan; the economic boost the boom has offered to producers including Australia, Russia, and Indonesia; or their rising importance of resource cooperation on the agendas of regional organisations such as APEC and ASEAN. However, during the global boom intergovernmental resource relationships became strained, as disputes emerged between producer and consumer governments over how the benefits of interdependence will be shared. Questions over resource access and scarcity have also become implicated in a range of geostrategic rivalries emerging amongst China, Russia, Japan and the United States (Leverett 2009; Wilson 2014). In the IR literature, it has become common to identify these resource conflicts as one of the most potentially destabilising factors facing the region in coming years (Herberg 2010; Hughes 2011; Jain 2014; Phillips 2013). The Asia-Pacific thus provides an ideal test case to explore the drivers of resource conflict and cooperation.

International resource politics in the Asia-Pacific intersects with questions about the growing global role of so-called rising powers. One of the distinguishing features of contemporary international politics is the increasing economic weight, diplomatic influence and military significance of a range of developing countries (Gray and Murphy 2013; Lo and Hiscock 2014). Many of these states are key players in regional resource politics, including import-dependent consumers of China and India, and export-oriented producers such as Russia, Indonesia, and Brazil. But equally importantly, natural resources are a key factor in these countries' rising international status. For example, Russia and Brazil have been identified as putative 'energy superpowers', whose growing diplomatic clout depends in some part on their role as energy exporters (Rutland 2008; Sennes and Narciso 2009). The growing international profile of China has also been bolstered by their resource diplomacy programs seeking new 
suppliers in Latin America, Africa and Central Asia (Brautigam 2009; Economy and Levi 2014). The recently established BRICS Summit - a body advocating for a more 'developing-country friendly' approach to global economic governance - has also made resource cooperation a key plank of its early institution-building efforts (Wilson 2015b). Dynamics of resource politics of the Asia-Pacific therefore have significant implications for the evolving role of rising powers in the early 21 st century.

The political-economy analysis developed through this book also has broader implications for the future of international politics in the AsiaPacific. Disputes over natural resources have become a key feature of regional politics, that many analysts attribute to emerging geopolitical tensions between its major powers (Chan et al. 2012; Herberg 2010; Phillips 2013; Tow 2007). However, the analysis offered here suggests they have deeper - and somewhat more intractable - causes. Securitisation and economic nationalism have been partially driven by the global resource boom of the 2000s and the resource security crisis posed by high prices. Statespecific political factors have also contributed. For some supplier governments resources are a matter of regime security, particularly the rentier states in the Middle East. For consumers in Northeast Asia, resources are critical for national economic security. For geopolitical aspirants in the region - particularly Russia and China - resource statecraft has also become an indispensable component in their foreign policy toolkits. This suggests that inter-state resource conflicts are not simply a side-effect of emerging geopolitical tensions in the region, but are driven by the securitisation of resource policy itself. This has emerged due to the economic effects of soaring world resource prices, and the political institutions that influence policymaking. As the latter are deeply ingrained in the political systems of many Asia-Pacific states, these conflicts are likely to be a lasting feature of regional politics.

\section{OUTLINE OF THE BOOK}

This book is organised into four parts. Part I develops a political-economy framework to theorise the role of natural resources in international politics. It reviews existing IR approaches, identifying their bias towards systemic theorising as a problem that obscures domestic political dynamics and the causes of securitisation. It then develops the theoretical argument linking securitisation to patterns of international resource politics. It begins by theorising the securitisation process, linking this to the special role of resources in the economic, regime and geopolitical security of many governments. Securitisation in turn leads governments to adopt economic nationalist 
policies which grant state agencies a high degree of control over resource sectors. This creates political conditions that lend themselves to inter-state disputes: by fostering sovereignty-consciousness, encouraging 'go-it-alone' responses to resource security, and undermining cooperative efforts to promote interdependence and open markets. This predicts that conflict behaviour is likely to emerge when securitising pressures are high - either due to an upswing in world market cycles, and/or the presence of states whose political characteristics predispose them towards competitive behaviour.

Part II begins the empirical analysis of the Asia-Pacific, by reviewing governmental approaches to resource security during the last decade. Chapter 3 focusses on consumer states, examining how the region's import-dependent economies have all recently turned towards resource mercantilism. These strategies are linked to economic security issues such as the protection of important domestic constituencies, as well as geopolitical concerns which reduce the perceived reliability of world markets. Chapter 4 turns attention to producer countries, identifying resource nationalism - a state strategy to exercise control over resource industries as a defining feature of the recent global boom. It argues that resource nationalism is a response to securitising pressures related to regime security (in rentier states), economic security (in developing economies) and geopolitical security (in states with geopolitical environments). The diplomatic interactions between producer and consumer states are then considered in Chapter 5. This evaluates regional resource cooperation initiatives, recently launched through ASEAN, APEC and their associated bodies. It demonstrates how securitisation and nationalism have made governments unwilling to commit to anything but low-cost - and largely ineffective - soft-law responses to resource insecurity. Taken together, these governmental strategies have created an environment conducive to the outbreak of inter-state resource conflict.

Part III explores the implications of these dynamics through case studies of three significant regional resource conflicts. Chapter 6 reviews the mercantilistic scramble among the Japanese, Korean and Chinese governments to acquire resource projects abroad. While this has seen their national oil companies collectively acquire over 100 new energy projects, internecine competition has seen the governments waste billions on ineffective and costly investments. Compounding matters, they have also become drawn into direct diplomatic clashes, particularly maritime disputes in the East and South China Seas. Chapter 7 explores the 'iron ore war' between governmental and corporate actors in China and Australia. Despite clear economic complementarity, economic nationalism has seen their minerals relationship almost irrevocably break down due to disputes over investment, pricing and the manipulation of markets. Chapter 8 then offers a 
case study of the international dispute over rare earth minerals. Driven by a range of securitising pressures - occurring both in China and its trade partners - rare earth minerals have proven an unexpected source of international conflict. They have produced a series of diplomatic clashes among China, Japan and the United States, a race to sponsor production 'anywhere but China', and led to a trade dispute which has recast the principles of international law for natural resources. These case studies demonstrate how securitisation has produced increasingly fractious resource relationship in the region.

Part IV integrates the principal conclusions, before turning attention to their implications for the future of international resource politics in the Asia-Pacific. It begins by summarising the core findings of the study: that conflict in international resource politics is driven by securitisation, which has been intensifying in the Asia-Pacific since the mid-2000s. It then explores how these dynamics are likely to develop in future years, particularly given the 'bust' phase which began in world resource markets in 2014. While falling prices have already contributed to a partial de-securitisation of resource policy, conflictual behaviour is likely to continue due to underlying political factors within important states. While resource insecurity remains an existential problem for regional governments such as China, Japan and Korea, they will remain committed to conflictual economic nationalist policies. In many producer states, the securitisation of resources is as much to do with domestic regime security as movements in international prices, and will persist through market downturns. For rising powers in the region - especially China and Russia - the intersection between geopolitical aspirations and the strategic importance of resources make their future de-securitisation unlikely. Resources can be expected to contribute to conflict tendencies in the Asia-Pacific for some years yet.

\section{NOTES}

1. Author's calculations, from (Energy Information Administration 2014a; World Steel Association, various years).

2. Author's calculations, from (Energy Information Administration 2014a).

3. The ASEAN+3 comprises Brunei, Cambodia, China, Indonesia, Japan, Korea, Laos, Malaysia, Myanmar, the Philippines, Singapore, Thailand, and Vietnam.

4. Author's calculations, from (UNCTAD 2016).

5. On the regional segmentation of resource markets, see Warell (2005) for coal; Hulbert and Goldthau (2013) for natural gas; Wilson (2012a) for iron ore; and Luo and Soria (2007) for aluminium. Oil is an exception, where regional markets are globally integrated through price and trade linkages (Bachmeier and Griffin 2006).

6. Author's calculations, from (Energy Information Administration 2014a). 